\title{
The Effects of Supplementing Whole Milk with Juniper (Juniperus oxycedrus) Aromatic Water on Growth and General Health Parameters of Holstein Calves
}

\author{
Ali Riza Isik ${ }^{1}$, Serkan Ozkaya ${ }^{1, *(\mathbb{D})}$ \\ ${ }^{1}$ Isparta University of Applied Sciences, Agriculture Faculty, Department of Animal Science, Isparta, TURKEY. \\ *Corresponding author
}

\section{Article History}

Received: 09 April 2021

Accepted: 03 May 2021

First Online: 15 May 2021

\section{Corresponding Author}

E-mail: serkanozkaya@isparta.edu.tr

\section{Keywords}

Juniper

Aromatic water

Calf

Growth

Health

Holstein

\begin{abstract}
The illness of the calves during the suckling period suppresses the growth of calves and causes them to be removed from the breeders. In the present study, it was investigated whether Juniper aromatic water (JOW) would be suitable for promoting healthy growth performance of suckling Holstein calves. Twelve newborn calves ( $n=3$, in each group) were randomly selected and assigned to the following four treatments: Control, 50, 100 and $200 \mathrm{ml} \mathrm{JOW}$ supplemented milk per day. The supplementation of JOW showed an increase in calves' live weight and body measurements. In addition, the supplementation of whole milk with JOW decreased the frequency of occurrence of calves' diarrhea and disease. The best result was observed in the supplementation of whole milk with $50 \mathrm{ml} \mathrm{JOW}$. The findings of the study showed that Juniper aromatic water, a by-product, can be used safely in the healthy rearing of calves.
\end{abstract}

\section{Introduction}

In newborn calves, resistance to diseases is low due to insufficient immune system. Antibiotic treatments applied during this period reduce the numbers of pathogens and also non-pathogenic bacteria. This causes the growth to stop or decline in the early period and therefore it causes economic losses (Soltan, 2009). The restriction and/or prohibition of the use of antibiotics in livestock have increased the interest in medicinal aromatic plants in recent years (Anadon, 2006).

The juniper, which is the subject of our study, has an important place in medicine manufacturing industry in Europe and many countries of the world because of its pharmacological properties medicine, due to and the extractive substances it contains. The juniper has been used as wood and material for making medicine from its fruits and leaves for many years in Anatolian geography as well as over the world. Medicines have been prepared from fruits and leaves for curing pain, cough, rheumatism, tuberculosis and it has also been used as antibacterial (Tumen and Hafizoglu, 2003). It has been determined that the JOW has selective antibacterial properties, also show antioxidant and iron-reducing properties depending on the concentration used (Isik et al., 2020).

There are a few studies on the use of aromatic waters, a by-product of extracting plant extracts, in animal nutrition and breeding and their health effects. In this study, it was aimed to investigate the effects of aromatic water, which is produced as a by-product and has no economic value, on the healthy growth of calves while extracting oil from juniper (Juniperus oxycedrus) fruits and leaves.

\section{Materials and Methods}

The study was approved by the MAKÜ animal experiments local ethics committee with decision dated 04.10.2019 and numbered 507.

\section{Animals and Dietary Treatments}

The study was carried out in Isparta University of Applied Sciences, Faculty of Agriculture, Education, 
Research and Application farm and 12 holstein calves were used, whose birth weight were the closest to each other. Power analysis method were used in determining the number of calves which was found as 3 calves in each group with the highest mean value of 4.73 , the lowest mean value of 4.34 and the standard deviation of 0.3 for $95 \%$ power. In order to eliminate the colostrum effect, calves were experimented at the 4-day-old after suckling with colostrum for 3 days. Calves housed in individual boxes were provided by ad libitum to starter and clean water. A total of 4 I whole milk (WM) in the morning (2L) and in the evening (2L) was given to the calves in equal portions. Experimental groups were formed as follows: (CNT) control diet (4 I WM), (D1) control diet (4 I WM) + $50 \mathrm{ml}$ aromatic water (1.25\% JOW added milk), (D2) control diet (4 I WM) + $100 \mathrm{ml}$ aromatic water (2.5\% JOW added milk), (D3) control diet ( 4 I WM) $+200 \mathrm{ml}$ aromatic water (5\% JOW added milk). JOW doses were determined according to Minimum Inhibition Concentration analysis results (Isik et al. 2020). The chemical composition of starter and whole milk used in the study is presented in Table 1. The crude protein and ether extract ratio of starter used in the study was determined according to method 954.01 and 920.39, respectively (AOAC, 1990). Metabolic energy was calculated according to Turkish Standards Institution (TSE, 1991). Fat\% (Method: IDF 141C:2000), protein\%) method: IDF 141C:2000), lactose\% (Methods: IDF 141C:2000) of WM were analyzed using a Bentley B150 milk analyzer (Bentley Combi 150, Bentley Instruments, Inc. Minnesota, Chaska, USA).

\section{Sample Collection}

Live weight and body measurements of calves were monitored weekly until weaning. Starter and water were drawn from the calves in the evening before the weighing, and the calves were weighed when their stomach were empty. The feed consumption of calves was recorded daily by using $1 \mathrm{~g}$ sensitive electronic scales (TESS, Comak Tarti LTD., Turkey). In this way, calves consuming $800 \mathrm{~g}$ of feed on consecutive days were determined and weaned.
Body measurements (Body length (BL), body depth (BD), withers height $(\mathrm{WH})$, and hip height $(\mathrm{HH})$ and chest girth (CG)) of calves were recorded weekly.

Blood samples were taken from vena jugularis of calves at the beginning of the experiment and at the weaning. Total cholesterol TC, Triglycerides TG, glucose GLU, Urea, Creatine CREA, Albumin ALB, Total protein TP, liver enzymes (Alanin aminotransferase ALT, Aspartate aminotransferase AST, Alkaline phoshatase ALP, Gamma-glutamyltransfarase GGT, Lactate dehydrogenase LDH) were determined in blood samples. Blood samples were centrifuged at $3000 \mathrm{rpm}$ for 10 minutes, and the obtained blood serum was analyzed with Mindray BS120 Vet (Mindray Corporation, Nanshan, China).

The feces of calves were monitored daily and scored for consistency (Larson et al., 1977): 1- normal, 2- soft, 3- fluid, 4- juicy. The number of days with diarrhea (NDD) and illness of calves (NID) has been recorded. When the feces score (FS) is 3 and above, the calf was registered with diarrhea. The respiratory rate (RR) and pulse rate (PR) of calves were recorded daily. Respiratory scores (RS) of calves were determined by Heinrichs et al. (2003): 1- normal, 2mild cough, 3- moderate cough, 4- moderate to severe cough, 5- severe and chronic cough.

\section{Production and Analysis of JOW}

According to the method described in the European Pharmacopoeia (1975) a mixture of $200 \mathrm{~g}$ juniper fruits and leaves and $1.5 \mathrm{~L}$ tap water were placed in a Clevenger hydrodistillation device and JOW was separated from the juniper essential oil and collected in a distillation flask (5 L).

Total phenolic compounds of JOW were determined according to Singleton and Rossi (1965) using Folin-Ciocalteu colorimetric method and spectrophotometer (PG T80+ UV/VIS Spectrometer, PG Instruments Ltd. Leicestershire, UK) reading were made at $765 \mathrm{~nm}$ wavelength. Chromatographic analysis was used to reverse-phase high-performance liquid chromatography (Shimadzu Corp., Kyoto, Japan) for the determination of JOW components (Caponio et al., 1999).

Table 1. Chemical composition of WM which supplemented JOW and without JOW, and calf starter.

\begin{tabular}{lccccc}
\hline Ingredients, \% & CNT & D1 & D2 & D3 & Calf starter \\
\hline DM & 8.90 & 9.00 & 8.80 & 8.60 & 91.26 \\
CP & 3.20 & 3.20 & 3.20 & 3.10 & 17.55 \\
EE & 3.40 & 3.40 & 3.40 & 3.40 & 3.45 \\
Lactose & 4.90 & 4.90 & 4.90 & 4.70 & \\
Freezing point(--0) & 0.57 & 0.57 & 0.56 & 0.55 & \\
pH & 6.63 & 6.63 & 6.57 & & 2848.90 \\
ME, kcal kg- & & & & &
\end{tabular}

* DM: Dry matter, CP: Crude protein, EE: Ether extract, ME: Metabolic energy 
Antiradical activity was determined using 1,1diphenyl-2-picrylhydrazyil (DPPH) (Shimada et al., 1992). $1 \mathrm{~mL}$ of $0.2 \mathrm{mM}$ DPPH was added to $1 \mathrm{~mL}$ samples (at concentrations of 50,100, $250 \mathrm{ppm}$ ) and mixed well with vortex.

The readings were made at $517 \mathrm{~nm}$ after 30 minutes in the dark environment and room temperature. The free radical of the samples was calculated using the formula: Antiradical activity (\%): [(absorbance value of control - samples absorbance value) / (absorbance value of control)] x 100.

The iron reduction capacity was determined using the method of Oyaizu (1986). Accordingly, $2.5 \mathrm{~mL}$ of $200 \mathrm{mM}$ sodium phosphate buffer $(\mathrm{pH}: 6.6)$ and $2.5 \mathrm{~mL}$ of $1 \%$ potassium ferricyanidine were added and mixed with a $2.5 \mathrm{~mL}$ sample. After the samples were kept at $50{ }^{\circ} \mathrm{C}$ for 20 minutes, $2.5 \mathrm{~mL}$ of $10 \%$ trichloroacetic acid was added and centrifuged at $200 \mathrm{rpm}$ for 10 minutes.

A $5 \mathrm{~mL}$ of the upper phase was taken and $5 \mathrm{~mL}$ of deionized water and $1 \mathrm{~mL}$ of $0.1 \%$ ferric chloride were added on it. Then, the absorbance values of the samples at $700 \mathrm{~nm}$ wavelength were measured in the spectrophotometer. Comparison with synthetic antioxidants such as BHA (Butylated hydroxyanisole), BHT (Butylated hydroxytoluene) and Trolox (6-hydroxy2, 5, 7, 8-tetramethylchroman-2-carboxylic acid) as high absorbance value indicates high iron reducing capacity. The iron binding strength at the samples was revealed.

\section{Statistical Analysis}

The data obtained in the study were analyzed by analysis of variance (ANOVA), and the differences between groups were examined with Tukey test (Minitab 2017 v 18.1, Minitab Ltd. UK).

\section{Results}

\section{Components and Total Antioxidant Capacity of JOW}

The components of the JOW and their percentage values are presented in Table 2 . When the phenolic components of JOW were examined, it was observed that the highest component was $\alpha$ cedrol (54.43\%) and the lowest component was trans-pinocarveol (3.57\%).

The oxidant capacity, iron reduction capacity and total phenolic content of the JOW are shown in Table 3.

The total content of JOW was obtained as 1.84 $\mathrm{mg} \mathrm{GAE} / \mathrm{g}$. Antioxidant capacity and iron reducing capacity increased in parallel with the increase in concentration.

Table 2. Components and percentages of JOW.

\begin{tabular}{lc}
\hline Components & Percentages \\
\hline$\alpha$-Cedrol & 54.43 \\
Verbenone & 20.16 \\
Verbenol & 14.90 \\
Berneol & 6.04 \\
Trans-pinocarveol & 3.57 \\
\hline
\end{tabular}

\section{Growth Performance of Calves}

The effect of JOW supplementation on the growth performance of calves is shown in Table 4. The effect of JOW supplementation on the weaning age of calves was not found to be significant.

Table 3. Phenolic content, antioxidant capacity and iron reducing power of JOW.

\begin{tabular}{|c|c|c|c|c|c|c|}
\hline & TPC & Antiradical & Antiradical & Antiradical & Iron reducing & Iron reducing \\
\hline & mg GAE/g & $\%$ & $\%$ & $\%$ & $(50 \mu \mathrm{l} / 2.5 \mathrm{ml})$ & $(250 \mu \mathrm{l} / 2.5 \mathrm{ml})$ \\
\hline & Mean \pm SEM & $(50 \mu \mathrm{l} / \mathrm{ml})$ & $(100 \mu \mathrm{l} / \mathrm{ml})$ & $(250 \mu \mathrm{l} / \mathrm{ml})$ & Mean \pm SEM & Mean \pm SEM \\
\hline & & Mean \pm SEM & Mean \pm SEM & Mean \pm SEM & & \\
\hline JOW & $1.84 \pm 0.01$ & $29.49 \pm 0.02$ & $45.40 \pm 0.10$ & $70.43 \pm 0.13$ & $0.49 \pm 0.01$ & $4.46 \pm 0.02$ \\
\hline Trolox & --------------- & $85.20 \pm 0.20$ & $91.30 \pm 0.30$ & $97.25 \pm 0.25$ & $3.32 \pm 0.02$ & $10.93 \pm 0.03$ \\
\hline BHT & --------------- & $94.70 \pm 0.21$ & $94.80 \pm 0.25$ & $97.53 \pm 0.08$ & $6.31 \pm 0.01$ & $23.65 \pm 0.02$ \\
\hline BHA & --------------- & $97.30 \pm 0.23$ & $96.75 \pm 0.15$ & $98.70 \pm 0.20$ & $3.62 \pm 0.02$ & $18.52 \pm 0.02$ \\
\hline
\end{tabular}

* TPC: Total phenolic content, BHT: Butylated hyroxytoluene, BHA: Butylated hyroxyanisole 
However, the trial groups tended to be weaned early compared to be CNT.

Numerical differences between initial and final live weight (LW) of calves were found to be significant $(P<0.05)$. Similarly, no significant differences were found between daily live weight gain (DLWG) and total live weight gain (TLWG) averages.

The effect of JOW supplementation on body measurements of calves was not found to be significant. However, it tended to improve the growth of calves.

The difference between the daily feed consumption (DFC) averages of groups was found to be significant $(P<0.05)$. While the highest DFC was obtained in D1, the lowest consumption was in CNT.

\section{Healthy Parameters of Calves}

The numerical difference among the averages of all values observed as health parameters of groups (Table $5)$ was found significant $(P<0.05)$.

Among these parameters, the highest average values for $R R, P R$ and RT were observed in D3, while the highest RS value was obtained in CNT.

Results revealed that illness and diarrhea were less common in the calves in the trial groups compared to the CNT, and when Table 5 is examined, it can be seen that the FS, NDD and NID values were higher in the CNT than the others.

Table 4. Effects of JOW supplementation on calves' growth performance.

\begin{tabular}{lccccc}
\hline & $\begin{array}{c}\text { CNT } \\
\text { Mean } \pm \text { SEM }\end{array}$ & $\begin{array}{c}\text { D1 } \\
\text { Mean } \pm \text { SEM }\end{array}$ & $\begin{array}{c}\text { D2 } \\
\text { Mean } \pm \text { SEM }\end{array}$ & Mean \pm SEM & P value \\
\hline Weaning age, $d$ & $44.33 \pm 2.91$ & $36.67 \pm 1.86$ & $43.33 \pm 2.85$ & $42.67 \pm 2.33$ & 0.21 \\
Initial LW, kg & $42.33 \pm 5.67$ & $42.17 \pm 1.69$ & $41.17 \pm 1.64$ & $40.33 \pm 1.86$ & 0.97 \\
Final LW, kg & $56.17 \pm 6.72$ & $56.33 \pm 1.17$ & $57.67 \pm 2.35$ & $54.67 \pm 4.76$ & 0.97 \\
DLWG, kg & $0.313 \pm 0.02$ & $0.386 \pm 0.01$ & $0.386 \pm 0.04$ & $0.330 \pm 0.09$ & 0.63 \\
TLWG, cm & $13.83 \pm 1.09$ & $14.16 \pm 0.88$ & $14.50 \pm 0.76$ & $14.33 \pm 4.38$ & 0.85 \\
TBLG, cm & $7.50 \pm 1.04$ & $9.33 \pm 0.67$ & $11.00 \pm 1.80$ & $9.67 \pm 1.69$ & 0.41 \\
TBDG, cm & $3.33 \pm 0.16$ & $3.83 \pm 0.88$ & $5.33 \pm 1.09$ & $6.10 \pm 0.44$ & 0.08 \\
TWHG, cm & $5.16 \pm 0.60$ & $8.67 \pm 1.30$ & $7.83 \pm 1.01$ & $6.66 \pm 0.72$ & 0.12 \\
THHG, cm & $5.33 \pm 0.44$ & $7.16 \pm 0.44$ & $7.67 \pm 1.09$ & $6.50 \pm 0.76$ & 0.21 \\
TCGG, cm & $8.33 \pm 0.66$ & $8.17 \pm 0.44$ & $11.17 \pm 0.60$ & $11.50 \pm 1.80$ & 0.49 \\
DFC, kg & $0.237 \pm 0.02^{\mathrm{B}}$ & $0.327 \pm 0.03^{\mathrm{A}}$ & $0.281 \pm 0.02^{\mathrm{AB}}$ & $0.246 \pm 0.03^{\mathrm{B}}$ & 0.01
\end{tabular}

* LW: Live weight, DLWG: Daily weight gain, TLWG: Total live weight gain, TBLG: Total body length gain, TBDG: Total body depth gain, TWHG:

Total wither height gain, THHG: Total hip height gain, TCGG: Total chest girth gain, DFC: Daily feed consumption, A,B: Shows the difference between averages on the same row

Table 5. Health parameters of calves.

\begin{tabular}{|c|c|c|c|c|c|}
\hline & $\begin{array}{c}\text { CNT } \\
\text { Mean } \pm \text { SEM }\end{array}$ & $\begin{array}{c}\text { D1 } \\
\text { Mean } \pm \text { SEM }\end{array}$ & $\begin{array}{c}\text { D2 } \\
\text { Mean } \pm S E M\end{array}$ & $\begin{array}{c}\text { D3 } \\
\text { Mean } \pm \text { SEM }\end{array}$ & $P$ value \\
\hline RR & $79.06 \pm 0.49^{\mathrm{B}}$ & $72.89 \pm 0.63^{C}$ & $70.98 \pm 1.06^{C}$ & $82.03 \pm 0.32^{A}$ & 0.00 \\
\hline PR & $82.99 \pm 0.52^{\mathrm{B}}$ & $82.37 \pm 0.59^{B}$ & $82.90 \pm 0.62^{\mathrm{B}}$ & $85.26 \pm 0.42^{\mathrm{A}}$ & 0.00 \\
\hline RS & $1.15 \pm 0.03^{A}$ & $1.00 \pm 0.00^{\mathrm{B}}$ & $1.05 \pm 0.02^{\mathrm{B}}$ & $1.01 \pm 0.01^{\mathrm{B}}$ & 0.00 \\
\hline FS & $2.08 \pm 0.06^{A}$ & $1.44 \pm 0.05^{\mathrm{B}}$ & $1.52 \pm 0.06^{\mathrm{B}}$ & $1.94 \pm 0.05^{\mathrm{A}}$ & 0.00 \\
\hline $\mathrm{RT},{ }^{\circ} \mathrm{C}$ & $38.54 \pm 0.03^{B}$ & $38.39 \pm 0.03^{C}$ & $38.52 \pm 0.03^{B}$ & $38.82 \pm 0.03^{A}$ & 0.00 \\
\hline NDD & $10.00 \pm 2.31^{\mathrm{A}}$ & $0.33 \pm 0.33^{\mathrm{B}}$ & $3.33 \pm 3.33^{A B}$ & $5.67 \pm 1.20^{\mathrm{AB}}$ & 0.04 \\
\hline NID & $2.67 \pm 1.33^{\mathrm{A}}$ & $0.00 \pm 0.00^{\mathrm{B}}$ & $0.33 \pm 1.00^{\mathrm{B}}$ & $0.00 \pm 0.00^{\mathrm{B}}$ & 0.03 \\
\hline
\end{tabular}

\footnotetext{
${ }^{*}$ RR: Respiratory rate, PR: Pulse rate, RS: Respiratory score, FS: Feces score, RT: Rectal temperature, NDD: Number of days with diarrhea, NID: Number of illness days, ${ }^{A B C}$ : Shows the difference between the averages in the same row.
} 


\section{Biochemical Blood Parameters of Calves}

Blood serum biochemical values of calves are shown in Table 6. Numerical differences among observed blood serum biochemical values of all groups were not found to be significant.

\section{Discussion}

\section{Components and Total Antioxidant Capacity of JOW}

In our study, $\alpha$-cedrol has the highest percentage in JOW components (Table 2) in line with Isik et al.'s (2020) study.

The total phenolic content of aromatic water obtained from different Juniper species shows differences. Indeed, Taviano et al. (2013) stated that the total phenolic contents of two different Juniper species used in their study were 5.14 and 17.89 mg GAE/g respectively, while Isik et al. (2020) and Miceli et al. $(2009,2011)$ reported the total phenolic contents of Juniper as $1.85 \mathrm{mg} \mathrm{GAE} / \mathrm{g}$ and $17.64 \mathrm{mg} \mathrm{GAE} / \mathrm{g}$ in their studies.

The impact of environmental conditions in the regions where Juniper grows may be the cause of this difference.

Many researchers reported that both essential oils and extracts obtained from Juniper species have high antioxidant properties and can be used instead of synthetic antioxidant (Elmastas et al., 2006; Loizzo et al., 2006; Miceli et al., 2009; Lesjak 2011; Isik et al., 2020). Our findings revealed that JOW can be used as an alternative of synthetic antioxidants at a concentration of $250 \mu \mathrm{l} / \mathrm{ml}$, JOW (Table 3). Iron reduction capacity, which has an important place in determining antioxidant activity (Menconi et al.,

Table 6. Effects of JOW supplementation on calves blood parameters.

\begin{tabular}{|c|c|c|c|c|c|}
\hline & $\begin{array}{c}\text { CNT } \\
\text { Mean } \pm \text { SEM }\end{array}$ & $\begin{array}{c}\text { D1 } \\
\text { Mean } \pm \text { SEM }\end{array}$ & $\begin{array}{c}\text { D2 } \\
\text { Mean } \pm \text { SEM }\end{array}$ & $\begin{array}{c}\text { D3 } \\
\text { Mean } \pm \text { SEM }\end{array}$ & $P$ value \\
\hline Initial ALT & $7.67 \pm 0.88$ & $13.67 \pm 2.40$ & $15.33 \pm 7.42$ & $16.33 \pm 7.13$ & 0.67 \\
\hline Final ALT & $8.00 \pm 2.08$ & $8.00 \pm 3.00$ & $14.00 \pm 2.89$ & $10.67 \pm 2.03$ & 0.35 \\
\hline Initial AST & $51.30 \pm 27.50$ & $56.00 \pm 14.60$ & $30.30 \pm 24.10$ & $141.00 \pm 103.00$ & 0.53 \\
\hline Final AST & $75.00 \pm 16.80$ & $43.70 \pm 22.40$ & $175.00 \pm 100.00$ & $49.70 \pm 22.20$ & 0.33 \\
\hline Initial GGT & $641.00 \pm 298.00$ & $766.00 \pm 272.00$ & $728.00 \pm 163.00$ & $1414.00 \pm 247.00$ & 0.19 \\
\hline Final GGT & $35.00 \pm 8.14$ & $56.00 \pm 18.50$ & $38.00 \pm 4.04$ & $44.33 \pm 4.10$ & 0.53 \\
\hline Initial ALP & $216.70 \pm 63.00$ & $340.30 \pm 50.00$ & $235.70 \pm 25.00$ & $171.30 \pm 7.70$ & 0.24 \\
\hline Final ALP & $150.00 \pm 12.50$ & $277.30 \pm 67.50$ & $206.70 \pm 12.50$ & $117.70 \pm 27.50$ & 0.07 \\
\hline Initial GLU & $125.70 \pm 11.20$ & $113.70 \pm 16.60$ & $116.70 \pm 16.20$ & $115.00 \pm 3.06$ & 0.91 \\
\hline Final GLU & $99.00 \pm 7.00$ & $98.00 \pm 7.64$ & $96.62 \pm 6.36$ & $92.33 \pm 2.33$ & 0.87 \\
\hline Initial TC & $60.30 \pm 28.70$ & $59.30 \pm 39.40$ & $41.30 \pm 23.60$ & $83.67 \pm 2.60$ & 0.75 \\
\hline Final TC & $151.70 \pm 20.30$ & $107.70 \pm 49.40$ & $138.30 \pm 56.60$ & $137.00 \pm 58.20$ & 0.92 \\
\hline Initial CREA & $1.38 \pm 0.22$ & $1.32 \pm 0.08$ & $1.32 \pm 0.06$ & $1.54 \pm 0.34$ & 0.86 \\
\hline Final CREA & $1.20 \pm 0.08$ & $1.40 \pm 0.06$ & $1.50 \pm 0.10$ & $1.22 \pm 0.15$ & 0.24 \\
\hline Initial UREA & $52.10 \pm 16.80$ & $29.30 \pm 15.40$ & $26.30 \pm 21.00$ & $72.40 \pm 26.60$ & 0.47 \\
\hline Final UREA & $47.30 \pm 23.40$ & $19.30 \pm 10.80$ & $53.40 \pm 24.50$ & $50.40 \pm 14.00$ & 0.59 \\
\hline Initial TP & $8.36 \pm 0.49$ & $7.60 \pm 0.38$ & $7.59 \pm 0.57$ & $7.62 \pm 0.24$ & 0.56 \\
\hline Final TP & $7.72 \pm 0.33$ & $7.45 \pm 0.07$ & $6.89 \pm 0.26$ & $6.96 \pm 0.35$ & 0.18 \\
\hline Initial ALB & $2.84 \pm 0.19$ & $2.76 \pm 0.09$ & $2.97 \pm 0.17$ & $2.73 \pm 0.02$ & 0.62 \\
\hline Final ALB & $3.39 \pm 0.07$ & $3.47 \pm 0.07$ & $3.26 \pm 0.21$ & $3.34 \pm 0.15$ & 0.77 \\
\hline Initial LDH & $648.00 \pm 35.70$ & $651.30 \pm 79.70$ & $763.00 \pm 152.00$ & $821.00 \pm 161.00$ & 0.68 \\
\hline Final LDH & $579.00 \pm 275.00$ & $713.70 \pm 57.30$ & $943.70 \pm 88.00$ & $822.30 \pm 19.30$ & 0.40 \\
\hline Initial TG & $35.00 \pm 12.70$ & $60.00 \pm 18.20$ & $47.67 \pm 9.74$ & $46.70 \pm 11.70$ & 0.64 \\
\hline Final TG & $27.33 \pm 7.31$ & $37.33 \pm 8.45$ & $34.67 \pm 5.17$ & $22.67 \pm 7.84$ & 0.50 \\
\hline
\end{tabular}


1995), increased in parallel with the increase in concentration of JOW (Table 3). Similarly, many researchers determined that the iron reduction capacity increases with an increase in the concentration (Elmastas et al., 2006; Djeridane et al., 2006; Miceli et al., 2009; Isik et al., 2020).

\section{Growth Performance of Calves}

The appetizing properties of medicinal herbs and their extracts stimulate digestion and increase feed consumption by promoting gastric and intestinal motility by increasing the release of enzymes.

Increasing feed consumption allows calves to be weaned at an early age (Tekeli et al., 2006; Kehoe et al., 2007; Ozkaya et al., 2018).

It has been reported that the reason that aromatic waters obtained from medical herbs improve the live weight of calves may be due to the positive effect of aromatic waters on the intestinal flora (Tiihonen et al., 2010; Sharma et al., 2013; Ozkaya et al., 2018). Chaves et al. (2008) have been stated that medicinal aromatic waters increase the digestibility of foods by increasing the total essential fatty acids concentration in the rumen and thus have positive effect on live weight gain. Herbal oils and extracts significantly increased the LW of calves (Ahmed et al., 2009; Soltan, 2009; Ghosh et al., 2010; 2011). However, in the study conducted with oregano aromatic water (OAW), Ozkaya et al. (2018) reported that the effect of OAW is not significant on the increase in LW of calves.

It was reported by Ozkaya et al. (2018) that the supplementation of OAW as a milk replacer tends to improve the body measurements of calves, but the numerical differences are not significant and supplementing JOW to milk showed similar results. Similarly, Unlu and Erkek (2013) reported that effect of oregano oil supplementation on the body measurements of calves is not significant.

Herbal extracts improve the digestion of feeds by increasing saliva, gall and enzyme activities. However, it increases the digestion and absorption capacity of the intestine by increasing the ability of epithelium cells to regenerate villi as a result of suppression pathogenic bacteria in the intestine (Maurao et al., 2006). The findings obtained in the study are line with Ghosh et al. (2010; 2011) who reported that herbal extracts significantly increased feed consumption. However, there are studies reporting that herbal extracts and aromatic waters do not effect feed consumption (Soltan, 2009; Unlu and Erkek, 2013; Ozkaya et al., 2018). The difference between these results may cause systemic losses due to mucosal secretion of herbal extracts (Jamroz et al., 2006).

\section{Healthy Parameters of Calves}

Supplementation oregano aromatic water (OAW) has no effect on the RR of calves (Ozkaya et al., 2018). Calves have higher RRs than adults (Plumb, 2005). However, $200 \mathrm{ml}$ JOW supplementation significantly increased the RR of calves (Table 5). The fact that the NID was low in the trial groups compared to the CNT indicated that the high RR was not associated with the disease. It is thought that calves being more active than adults increase RR.

It has been reported that OAW supplementation significantly increases PR of calves (Ozkaya et al., 2018). Just as increase in activity increases the RR, it also increases the PR (Akgun, 1989). Calves have higher PRs than adults, just like their RRs (Plumb, 2005). For this reason, it is thought that the reason why PRs higher in trial groups compared to CNT is due to the active and excited calves rather than the disease.

Although the difference among the RT of the groups was found to be significant (Table 5), the average values remained within the normal limits (38.6-39.4 ${ }^{\circ} \mathrm{C}$ ) for calves (Latimer et al., 2003). It has been reported by many researchers RT rises above $39.5{ }^{\circ} \mathrm{C}$ in both respiratory and digestive system disease (Griffin, 1997; Smith, 2000; Gunes, 2018).

Due to the antibacterial properties and iron reduction capacity of oils and extracts of aromatic plants, they are positive effects on intestinal bacterial flora and suppress pathogenic bacteria. Therefore, plant oil and extracts significantly reduce the FS (Ishihara et al., 2001; Goetz et al., 2002; Lewis et al., 2003; Ghosh et al., 2010; 2011; Ozkaya et al., 2018). This explains the low FS in the trial groups (Table 5). However, there are studies indicating that oil and extracts obtained from plants have no effect on the FS (Greathead et al., 2000; Bampidis et al., 2005; Unlu ve Erkek, 2013).

Digestive system diseases suppress the growth of calves and cause death (Davis and Drackley, 1998; NAHMS, 2007). The antibacterial properties of herbal extracts suppress the growth of pathogenic bacteria such as E. coli, Coliforms and Enterobacteriaceae in the intestinal flora, thereby improving the immune system and reducing the incidence of diarrhea (Ahmed et al., 2009; Ozkaya et al., 2018). The reason for the low NDD 
is thought to be the suppression of the growth of pathogenic bacteria due to the antibacterial effects of JOW (Table 5).

Oils and their extracts obtained from medicinal aromatic plants support the immune system and reduce the incidence of disease cases in calves (El-Ashry et al., 2006; Ahmed et al., 2009; Franz et al., 2010; Li et al., 2012a; 2012b; Wang et al., 2012; Sajjadi et al., 2014, Zeng et al., 2015; Ozkaya et al., 2018). The reason for the low NID in the trial groups may be associated with an immune system supporting effect of JOW (Table 5).

\section{Conclusion}

The supplementation of JOW tended to improve the growth performance, increased feed consumption, reduced the incidence of diarrhea and disease of calves and enabled healthy calves rearing. The fact that no negative effects were observed in blood serum biochemical variables which is an indicator of the healthy growth and good animal welfare for calves. It was concluded that applied JOW doses could be used for rearing healthy calves, but calves reared with $50 \mathrm{ml} \mathrm{JOW}$ supplemented milk (1.25\% JOW supplemented milk) showed healthier growth calves compared to other groups.

It is recommended to examine the effects of JOW supplementation on fecal bacteria count, immune system and antioxidative defense parameters in order to better reveal the effects of JOW on both the growth and health of calves.

\section{Acknowledgement}

We would like to thank Isparta University of Applied Sciences Scientific Research Projects Coordination Unit for their financial support of the study (Project No: 2019-YL1-0016).

\section{References}

Ahmed, A. A., Bassuony, N. I., Awad, S., El-Habiab, S., Aiad, A. M., \& Mohamed, S. A. (2009). Adding natural juice of vegetable and fruitage to ruminant diets (B) nutrients utilization, microbial safety and immunity, effect of diets supplemented with lemon, onion and garlic juice fed to growing buffalo calves. World J. Agric. Sci. 5(4): 456-465.

Akgun, N. (1989). Egzersiz fizyolojisi, 1. Baskı, Ankara. (In Turkish)

AOAC (1990). 'Official Methods of Analysis, Method 954.01 and Method 920.39, protein (crude) and fat (crude) or ether extract in animal feed.' 15th edn., (AOAC International, Arlington, VA).
Anadon, N. A. (2006). The EU ban of antibiotics as feed additives: Alternatives and consumers safety. J. Vet. Pharmacol. Ther. 29(1): 41-46.

Bampidis, V. A., Christodoulou, V., Florou-Paneri, P., Christaki, E., Spais, A. B., \& Chatzopolou, P. S. (2005). Effect of dietary dried oregano leaves supplementation on performance and carcass characteristics of growing lambs. Anim. Feed Sci. Technol. 121: 285-295. DOI: 10.1016/j.anifeedsci.2005.02.002.

Caponio, F., Alloggio, V., \& Gomes, T. (1999). Phenolic compounds of virgin olive oil: influence of paste preparation techniques. Food Chem. 64: 203-209.

Chaves, A. V., Stanford, K., Gibson, L. L., McAllister, T. A., \& Benchaar, C. (2008). Effects of carvacrol and cinnamaldehyde on intake, rumen fermentation, growth performance, and carcass characteristics of growing lambs. Anim. Feed Sci. Technol. 145: $396-$ 408. DOI: 10.1016/j.anifeedsci.2007.04.016.

Davis, C. L., \& Drackley, J. K. (1998). The development, nutrition and management of the young calf. lowa State University Press, $339 \mathrm{pp}$.

Djeridane, A., Yousfi, M., Nadjemi, B., Boutassouna, D., Stocker, P., \& Vidal, N. (2006). Antioxidant activity some Algerian medicinal plants extracts containing phenolic compounds. Food Chem. 97: 654-660. DOI: 10.1016/j.foodchem.2005.04.028.

El-Ashry, M. A., El-Bordery, N. E., Khattab, H. M., \& ElSayed, H. M. (2006). Effect of diet supplemented with medicinal herbs on nutrient digestibility and some blood parameters of buffalo calves. Egyptian J. Nutr. Feeds. 2: 179-191.

Elmastas, M., Gulcin, I., Beydemir, S., Kufrevioglu, O. I., \& Aboul-Enein, H. Y. (2006). A study on the in vitro antioxidant activity of Juniper (Juniper communis L.) fruit extracts. Anal. Lett. 39(1): 47-65. DOI: 10.1080/00032710500423385.

European Phamacopoeia (1975). European Pharmacopoeia. 3. Maissonneuve. Sainte-Ruffine, p.68.

Franz, C., Baser, K. H. C., \& Windisch, W. (2010). Essential oils and aromatic plants in animal feeding a European perspective: a review. Flavour Fragr. J. 25: 327-340. DOI: 10.1002/ffj.1967.

Ghosh, S., Mehla, R. K., Sirohi, S. K., \& Roy, B. (2010). The effect of dietary garlic supplementation on body weight gain, feed intake, feed conversion efficiency, faecal score, faecal coliform count and feeding cost in crossbred dairy calves. Trop. Anim. Health Prod. 42: 961-968. DOI: 10.1007/s11250-009-9514-5.

Ghosh, S., Mehla, R. K., Sirohi, S. K., \& Tomar, S. K. (2011). Performance of crossbred calves with dietary supplementation of garlic extract. J. Anim. Physiol. Anim. Nutr. 95: 449-455. DOI: 10.1111/j.14390396.2010.01071.x.

Greathead, H. M. R., Forbes, J. M., Beaumont, D., \& Kamel, C. (2000). The effect of a formulation of natural essential oils used as an additives with milk replacer and a compound feed on the feed efficiency of calves. British Society of Animal Sciences, Annual Winter Meeting, pp.68. 
Griffin, D. (1997). Economic impact associated with respiratory disease in beef cattle. Vet. Clin. N. Am. Food A. 13: 367377. DOI: 10.1016/s0749-0720(15)30302-9.

Goetz, D. H., Holmes, M. A., Borregaard, N., Bluhm, M. E., Raymond, K. N., \& Strong, R. K. (2002). The neutrophil lipocalin NGAL is a bacteriostatic agent that interferes with siderophore -mediated iron acquisition. Mol. Cell. 10(5): 1033-1043. DOI: 10.1016/S1097-2765(02)007086.

Gunes, V. (2018). Respiratory disease of calves. Lalahan Hayvancilik Arastırma Enstitusu Dergisi (Livestock Studies), 58 (Special Issue): 35-40 (In Turkish).

Heinrichs, A. J., Jonel, C. M., Van Roekel, L. R., \& Fowler, M. A. (2003) Calf track: A system of dairy calf work force management, training and evaluation and health evaluation. J. Dairy Sci. 86(1): 115.

Ishihara, N., Chu, D. C., Akachi, S., \& Junera, L. R. (2001). Improvement of intestinal microflora balance and prevention of digestive and respiratory organ disease in calves by green tes extracts. Livest. Prod. Sci. 68: 217229. DOI: 10.1016/s0301-6226(00)00233-5.

Isik, A. R., Ozkaya, S., Erbas, S., \& Koknaroglu, H. (2020). Determination of antibacterial and antioxidant activities of Juniper (Juniperus oxycedrus L.) essential oils and aromatic water. Erciyes Üniv. Vet. Fak. Derg. 17(2): 8894. DOI: $10.32707 /$ ercivet.760632.

Jamroz, D., Wertelecki, T., Houszka, M., \& Kamel, C. (2006). Influence of diet type on the inclusion of plant origin active substances on morphological and histochemical characteristics of the stomach and jejunum walls in chicken. J. Anim. Physiol. Anim. Nutr. 90: 255-268. DOI: 10.1111/j.1439-0396.2005.00603.x.

Kehoe, S. I., Dechow, C. D., \& Heinrichs, A. J. (2007). Effects of weaning age and milk feeding frequency on dairy calf growth, health and rumen parameters. Livest. Sci. 110: 267-272. DOI: 10.1016/j.livsci.2006.11.007.

Latimer, K. S., Mahaffey, E. A., \& Prasse, K. W. (2003). Duncan and Prasse's Veterinary Laboratory Medicine: Clinical Pathology, 4th Edn. 331-338.

Lesjak, M. M. (2011). Biopotential and chemical characterization of extracts and essential oils of species from Juniperus L. genus (Cupressaceae). PhD Thesis, University of Novi Sad, Faculty of Sciences, Serbia.

Lewis, M. R., Rose, S. P., Mackenzie, A. M., \& Tucker, L. A (2003). Effects of dietary inclusion of plant extracts on the growth performance of male broiler chickens. Br. Poult. Sci. 44 (Suppl. 1): S43-S44. DOI: 10.1080/713655281.

Loizzo, M. R., Tundis, R., Statti, G. A., Milijkovic-Brake, A., Menichini, F., \& Houghton, P. J. (2006). Bioactive extracts from Senecio samnitum Huet. Nat. Prod. Res. 20(3): 265269. DOI: $10.1080 / 14786410500077823$.

Li, S. Y., Ru, Y. J., Liu, M., Xu, B., Peron, A., \& Shi, X. G. (2012a). The effects of essential oils on performance, immunity and gut microbial population in weaned pigs. Livest. Sci. 145: 119-123. DOI: 10.1016/j.livsci.2012.01.005.

Li, P. F., Piao, X. S., Ru, Y. J., Han, X., Xue, L. F., \& Zhang, H. Y. (2012b). Effects of adding essential oil to the diet of weaned pigs on performance, nutrient utilization, immune response and intestinal health. Asian-Australas. J. Anim. Sci. 25: 1617-1626. DOI 10.5713/ajas.2012.12292.

Maurao, J. L., Pinheiro, V., Alves, A., Guedes, C. M., Pinto, L., Saavedra, M. J., Spring, P., \& Kocher, A. (2006). Effect of mannan oligosaccharides on the performance, intestinal morphology and cecal fermentation of fattening rabbits. Anim. Feed Sci. Technol. 25: 107120. DOI: 10.1016/j.anifeedsci.2005.06.009.

Menconi, M., Sgherri, C. L. M., Pinzino, C., \& Navari-Izzo, F. (1995). Activated oxygen production and detoxification in wheat plants subjected to a water deficit programme. J. Exp. Bot. 46(9): 1123-1130. DOI: 10.1093/jxb/46.9.1123.

Miceli, N., Trovato, A., Dugo, P., Cacciola, F., Donato, P., Marino, A., Bellinghieri, V., La Barbera, T. M., Guvenc, A., \& Taviano, M. F. (2009). Comparative analysis of flavonoid profile, antioxidant and antimicrobial activity of the berries of Juniperus communis L. var. communis and Juniperus communis L. var. saxatilis Pall. from Turkey. J. Agric. Food Chem. 57(15): 6570-6577. DOI: 10.1021/jf9012295.

Miceli, N., Trovato, A., Marino, A., Bellingheri, V., Melchini, A., Dugo, P., Cacciola, F., Donato, P., Mondello, L., Guvenc, A., De Pasquale, R., \& Taviano, M. F. (2011). Phenolic composition and biological activities of Juniperus drupacea Labill. berries from Turkey. Food Chem. Toxicol. 49(10): 2600-2608. DOI: 10.1016/j.fct.2011.07.004.

NAHMS (2007). National Animal Health Monitoring Systems, Part 1: Reference of dairy health management in the United States. USDA-APHIS; VS; CEAH.-Veterinary Services, Fort Collins, CO \#N480.1007.

Larson, L. L., Owen, F. G., Albright, J. L., Appleman, R. D., Lamb, R. C., \& Muller, L. D. (1977). Guidelines toward uniformity in measuring and reporting calf experimental data. J. Dairy Sci. 60: 989-991. DOI: 10.3168/jds.S0022-0302(77)83975-1.

Oyaizu, M. (1986). Studies on product of browing reaction. Antioxidative activities of products of browing reaction prepared from glucose amine. Jpn. J. Nutr. Diet. 44: 307-315. DOI: 10.5264/eiyogakuzashi.44.307.

Ozkaya, S., Erbas, S., Ozkan, O., Baydar, H., \& Aksu, T. (2018). Effect of supplementing milk replacer with aromatic oregano (Oreganum onites L.) water on performance, immunity and general health profiles of Holstein calves. Anim. Prod. Sci. 58: 1892-1900. DOI 10.1071/AN16574.

Plumb, D. C. (2005). Plumb's veterinary drug handbook, 5th edition, pp. 1241-1249.

Sajjadi, R., Solati, A. A., Motlagh, M. K., \& Bonchenari, M. K. (2014). Immune response and some blood metabolite responses of female Holstein calves to dietary supplementation with licorice root (Glycyrrhiza glabra). Iran. J. Appl. Anim. Sci. 4(3): 505-508.

Sharma, P., Mack, J. P., \& Rojtman, A. (2013). Ten highly effective essential oils inhibit growth of methicilin resistant Staphylococcus Aureus (MRSA) and methicillin sensitive Staphylococcus Aureus (MSSA) Int. J. Pharm. Pharm. Sci. 51(1): 52-54

Shimada, K., Fulikawa, K., Yahara, K., \& Nakamura, T. (1992). Antioxidative properties of xanthan of the autoxidation on soybean oil in cyclodextrin emulsion. J. Agric. Food Chem. 40: 945-948. DOI: 10.1021/jf00018a005. 
Smith, R. A. (2000). Effects of feedlot disease on economics, production and carcass. Bovine Pract. 33: 125-128.

Singleton, V. L., \& Rossi, J. R. (1965). Colorimetry of total phenolics with phosphomolibdic-phoshothungstic acid. Am. J. Enol. Vitic. 16: 144-158.

Soltan, M. A. (2009). Effect of essential oil supplementation on growth performance, nutrient digestibility, health condition of Holstein male calves during pre- and postweaning periods. Pak. J. Nutr. 8(5): 642-652. DOI: 10.3923/pjn.2009.642.652.

Taviano, M. F., Marino, A., Trovato, A., Bellinghieri, V., Melchini, A., Dugo, P., Cacciola, F., Donato, P., Mondello, L., Guvenc, A., De Pasquale, R., \& Miceli, N. (2013). Juniperus oxycedrus L. subsp. oxycedrus and Juniperus oxycedrus L. subsp. macrocarpa (Sibth. \& Sm.) Ball. "beries" from Turkey: Comparative evaluation of phenolic profile, antioxidant, cytotoxic and antimicrobial activities. Food Chem. Toxicol. 58: 22-29. DOI: 10.1016/j.fct.2013.03.049.

Tekeli, A., Celik, L., Kutlu, H. R., \& Gorgulu, M. (2006). Effects of Syzygium aromaticum and Zingiber officinale essential oils on performance and some carcass, blood and intestinal parameters of Broilers. 57th Annual Meeting of the European Association for Animal Production (EAAP). vol. 12, Antalya, Turkey, pp. 303.

Tiihonen, K., Kettunen, H., Bento, M. H., Saarinen, M.,
Lahtinen, S., Ouwehand, A. C., Schulze, H., \& Rautonen, N. (2010). The effect of feeding essential oils on broiler performance and gut microbiota. Br. Poult. Sci. 51: 381-392. DOI: 10.1080/00071668.2010.496446.

TSE (1991). Method of the determination metabolic (converted) energy of animal feeds. Turkish Standard Institution Standard No: 9610, Ankara, Turkey.

Tumen, I., \& Hafizoglu, H. (2003). Turkiye'de yetisen ardic (Juniperus L.) turlerinin kozalak ve yaprak ucucu yaglarinin bilesiminde bulunan terpen gruplari. Bartin Orm. Fak. Derg. 5(3): 88-95. (In Turkish)

Unlu, H. B., \& Erkek, R. (2013). Effects of oregano and garlic essential oils on performance of calves and some parameters of faeces and blood. Ege Üniv. Ziraat Fak. Derg. 50(3): 299-310.

Wang, F., Yan, Y., Zhang, Y., Han, Y., \& Guan, C. (2012). Effects of immune synergist of Chinese medicinal herbs on the efficacy of vaccination against classics wine fever. Afr. J. Biotechnol. 11(6): 1535-1539. DOI: 10.5897/AJB11.1366.

Zeng, Z., Xu, X., Zhang, Q., Li, P., Zhao, P. F., Li, Q., Liu, J., \& Piao, X. (2015). Effects of essential oil supplementation of a low-energy diet on performance, intestinal morphology and microflora, immune properties and antioxidant activities in weaned pigs. Anim. Sci. J. 86(3): 279-285. DOI: 10.1111/asj.12277. 